\title{
【論文】
}

\section{焼却炉排ガス中の放射性セシウム濃度測定方法の 粒子個数濃度測定による検証}

\author{
飯野翔太*高橋克 行 $^{*}$. 庄司貴 ${ }^{* *} \cdot$ 鹿島勇治 * \\ 小山陽介 ${ }^{* * *}$. 山本貴 士 ${ }^{* * * *}$. 大迫政 浩 ${ }^{* * * *}$
}

【要 旨】排ガス中の放射性セシウム濃度の測定は, 環境省が定めた公定法で実施されている。公定法 の放射性セシウム分析はろ紙とインピンジャ内の捕集液に対して行うが，排ガス中の放射性セシウムが ろ紙により十分に捕集されるとの知見は得られているものの, 微小粒子に対する万紙の捕集性能につい ては詳細なデー夕提供がなされていない。そこで本研究では, 実際の焼却炉排ガスに扔いて粒子個数濃 度の観点から公定法の評価を行った。その結果，バグフィルタ入口の微小粒子（粒径 $0.3 \mu \mathrm{m}$ 未満の粒 子）の個数濃度は $10^{6}$ 個 $\mathrm{cm}^{-3} \mathrm{~N}$ に対して, インピンジャ出口では $10^{2}$ 個 $\mathrm{cm}^{-3}{ }_{\mathrm{N}}$ であり, 公定法におい て微小粒子は 99.99 \% 程度捕集できることを明らかにした。さらにインピンジャ出口で検出された粒子 を捕集して放射性セシウムの分析をしたところ, 検出下限值未満であり, 公定法は排ガス中の放射性セ シウムの試料採取方法として適切であることが検証された。

キーワード：焼却炉排ガス，放射性セシウム，微小粒子，電子式低圧インパク夕（ELPI）, 走査式モビ リティパーティクルサイザ（SMPS）

\section{1. は じめ に}

福島県内の污染廃充物対策地域等に国が設置する仮設 減容化施設においては, 事故由来放射性物質に污染され た災害廃棄物等の減容化処理が行われている。これら仮 設減容化施設では定期的に焼却炉排ガス中の放射性セシ ウム $\left({ }^{134} \mathrm{Cs}\right.$ 抒よび $\left.{ }^{137} \mathrm{Cs}\right)$ 濃度を測定し, ホームページ1) で公表している。焼却炉排ガス中の放射性セシウムの測 定方法は, 環境省の「廃棄物関係ガイドライン第 5 部 放射能濃度等測定方法ガイドライン」2) (以下, 公定法) に定められており，JIS Z 8808 「排ガス中のダスト濃度

原稿受付 2017.9.27原稿受理 2018.6.23

*(-財) 日本環境衛生センター 東日本支局

***(-財) 日本環境衛生センター 総局

****国研国立環境研究所 環境リスク・健康研究センター

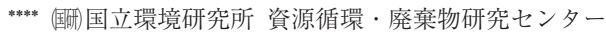
連絡先：干 210-0828 川崎市川崎区四谷上町 10-6

(一斯)日本環境衛生センター 東日本支局 環境事業本部 環境事業第二部 高橋 克行

E-mail : katsuyuki_takahashi@jesc.or.jp
測定方法」3) に準拠する方法を用いている。本法はろ紙 によってばいじんを捕集し, その後段にインピンジャを 設置して焼却炉排ガス中のガス成分を吸収液捕集する方 法となっている。放射性セシウム濃度の測定はろ紙とイ ンピンジャ内の捕集液 (以下, ドレン水) それぞれに対 して行う。公定法における検出下限值はろ紙部とドレン 水とも, ${ }^{134} \mathrm{Cs}$ と ${ }^{137} \mathrm{Cs}$ に対し $2 \mathrm{~Bq} \mathrm{~m}^{-3}{ }_{\mathrm{N}}\left(\mathrm{m}^{3}{ }_{\mathrm{N}}\right.$ とは $0{ }^{\circ} \mathrm{C}$, $101.32 \mathrm{kPa}$ の標準状態における気体の体積）が目標值と なっている。この目標值は集じん装置の出口側で 4 時間 $\left(3 \mathrm{~m}^{3}\right)$ 試料を採取した際の目標值である。環境省等が 実施した一般廃棄物処理施設の焼却炉排ガス測定の結 果 ${ }^{4-7)}$ によると, 集じん装置を経た焼却炉排ガス中の放 射性セシウムは, ごく一部の施設で検出された事例があ

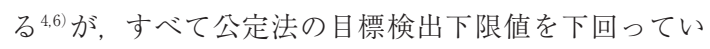
た。また, 採取試料量を増やし放射性セシウムの分析時 間を長くすることで検出下限值を公定法の 10,000 分の 1 程度とした事例 8 に扔いても, 放射性セシウムは検出さ れなかったとの報告例もある。他方, 集じん装置の入口 側で採取した焼却炉排ガスからは放射性セシウムが検出 されるが，その場合はろ紙部からの検出に限られ，ドレ 
ン水から検出されたケースは確認されていない ${ }^{5-7)} 。$

原子力施設における排ガス中の放射性セシウムの測定

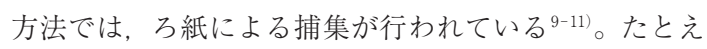
ば，原子炬施設の平常運転時に環境に放出される放射性 物質の放射能量を測定するために原子力安全委員会が定 めたものとして, 発電用軽水型原子炉施設における放出 放射性物質の測定に関する指針 ${ }^{9)}$ がある。当該指針では, 排ガス中で測定する ${ }^{134} \mathrm{Cs}$ と ${ }^{137} \mathrm{Cs}$ は粒子状物質に区分さ れており，ろ紙による捕集を行う。また, JIS Z 4601 「放射性ダストサンプラ」10) が制定されており，こちら もろ紙による捕集が採用され，原子力施設や放射線施設 の作業環境や排気系等の測定は, JIS Z 4601 が使用され ている。原子力安全委員会の指針と JIS Z 4601 のどちら の測定方法においても, 万紙部の後段にガス状物質を回 収する液体捕集部の設置は規定されておらず, 公定法と 採取方法は異なっている。これを受けて, 原子炉施設に おける測定方法と公定法との比較並行試験が実施されて いる。バグフィルタの入口側と煙突側にて公定法と JIS Z 4601 に準拠した手法とで比較した結果, バグフィル 夕の入口側の測定では測定法間で大きな差はなかったと 報告している ${ }^{12)}$ 。また, この比較並行試験においても, 煙突側ではどちらも検出下限值未満であった。比較並行 試験の結果や公定法による放射性セシウムの検出状況か ら, 焼却炉排ガス中のセシウムは粒子状物質として存在 し, ガス状物質の寄与は極めて小さいと考えられる。

公定法による焼却炉排ガス中の放射性セシウム濃度の 測定については安定セシウムを用いた検証試験が行われ ており, 加熱によって揮散させたセシウムのほぼ全量が

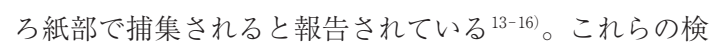
討は小型管状炉によるものであるが, 山本ら ${ }^{17)}$ は, 実際 の廃棄物焼却を想定した小型焼却炉にて, ごみ由来燃料 と安定セシウムを用いた排ガスの捕集試験を行っており， 既報と同様にセシウムはろ紙部からのみ検出され，ドレ ン水からは検出されていないと報告している。ドレン水 から放射性セシウムが検出されない理由については, 熱 力学的化学平衡計算 ${ }^{18)}$ とセシウム塩の飽和蒸気圧 ${ }^{19)}$ に基 づく検討が行われており, バグフィル夕入口の焼却炉排 ガスの温度条件では, 焼却処理によって発生すると推定

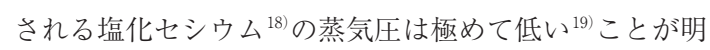
らかになっている。稼働中の都市ごみ焼却施設の集じん 装置入口側煙道内から採取したばいじん中に, 塩化セシ ウムの存在が確認された例 ${ }^{20)}$ も報告されており, 熱力学 的化学平衡計算は妥当なものと考元られる。以上の研究 結果は, バグフィルタ入口では焼却炉排ガス中に含まれ る蒸気状セシウム化合物は極めて少ないことを示唆して おり, ドレン水から放射性セシウムが検出されない主な
理由である。

しかしながら, 既報 ${ }^{13-17)}$ における検討は安定セシウム を用いたものであり, 污染廃棄物対策地域内に設置され た実機による試験ではない。また，ばいじん中に含まれ る放射性セシウム濃度は, 微小粒径になるほど高濃度に なるものと推定される ${ }^{12,21-23)}$ が, 公定法で用いる円筒ろ 紙の性能は粒径 $0.3 \mu \mathrm{m}$ の粒子を分散した大気を $5 \mathrm{~L}$ $\min ^{-1}$ で通気させたときに $99 \%$ 以上の捕集効率がある ものを用いると定められている ${ }^{3)}$ 。一方で粒径 $0.3 \mu \mathrm{m}$ 未満の粒子については記載がなく, 微小な粒子について は検証が必要であると考えられる。ただし, 環境省等の 調査結果 ${ }^{4-8)}$ から, 極低濃度の放射性セシウムをゲルマ ニウム半導体検出器等によって検出するのは困難である と想定されたことから, 他の手法によって検証する必要 があると考えられた。

そこで本研究では, 焼却炉排ガスに含まれる粒子の個 数濃度を測定する手法に着目した。粉じん除去用のフィ ルタユニットの性能試験を定めた JIS B 9908 「換気用エ アフィルタユニット・換気用電気集じん器の性能試験方 法」24) は, 質量法ではなく粒子の個数濃度を測定し, 個 数基準の捕集効率にて性能評価することが定められてい る。また, ナノ粒子を含む微小粒子の計測においては, 個数基準による測定のほうが質量法より精緻な評価が可

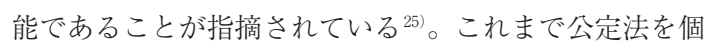
数濃度で評価した例は認められない。以上を踏まえ, 本 研究では公定法の検証を目的に, 個数濃度測定による粒 子捕集性能の評価を行った。

\section{2. 方法}

\section{1 試験施設}

ばいじん試料の採取等は, 福島県内の污染廃書物対策 地域内に設置された仮設減容化施設のうち, 稼働中の $\mathrm{A}$ 施設と $\mathrm{B}$ 施設の 2 施設で実施した。 $\mathrm{A}$ 施設および $\mathrm{B}$ 施設は東日本大震災によって発生した災害廃棄物のほか, 除染等の措置によって発生した廃棄物のうち可燃性廃棄 物を処理する施設である。両施設とも全連続式ストーカ 炉が設置されており, 集じん装置としてバグフィルタを 用いている。試験施設の焼却炉排ガス処理フローを図 1 および図 2 に示す。

\section{2 使用装置}

焼却炉排ガス中の粒子個数測定には高温用電子式低圧 インパクタ (HT ELPI+, DEKATI Ltd., 測定粒径範 囲 0.006 10 $\mu \mathrm{m}$ ：以下 ELPI と略記）を使用した。 ELPI はコロナチャージャ, インパクタ, エレクトロ 


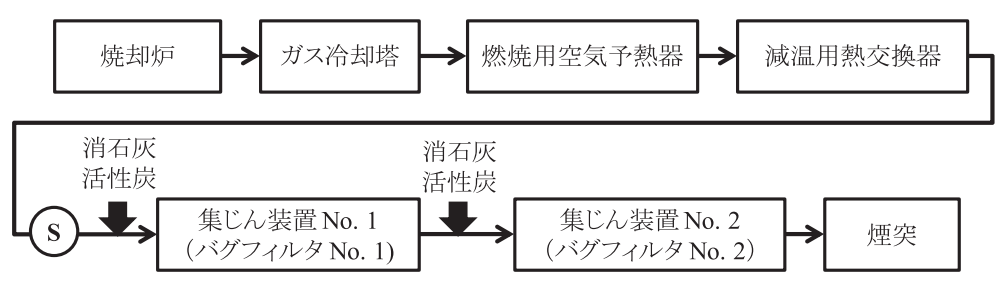

$S$ : 試料採取位置

図 1 A 施設における処理フロー

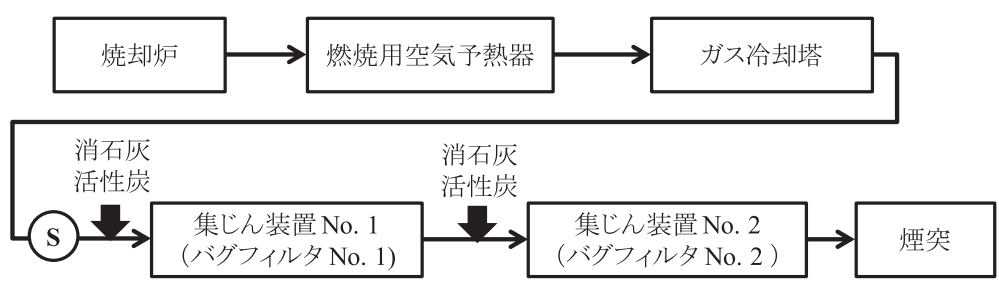

$\mathrm{S}$ : 試料採取位置

図 2 B 施設における処理フロー

メータで構成され, 多段インパクタによって空気動力学 径による分級を行い, 帯電粒子の捕集によって生じる電 流を各段ごとに測定することで粒径ごとの粒子個数濃度 を測定する装置である。また, 粒子個数濃度の換算に よって粒子質量濃度として評価することも可能である。 ELPI による測定值は 1 秒ごとに記録される。一方, 公 定法による試料採取で用いるインピンジャの出口側にお ける粒子個数の測定には, 粒子個数が非常に少ないこと が想定されたことから, 検出感度に優れる走査式モビリ ティパーティクルサイザ (SMPS, TSI Inc., 測定粒径 範囲 $0.01 \sim 0.34 \mu \mathrm{m}$ ：以下 SMPS と略記）を使用した。 SMPS は粒子分級部 (微分型静電分級器: DMA モデル 3082, TSI Inc.) と粒子検出部（凝縮性粒子カウンタ： CPC モデル 3772, TSI Inc.) で構成され, 静電分級器で 分級した粒子を光学的に検出し, 粒子個数濃度を測定す る装置である。SMPS による測定值は 1 分ごとに記録さ れる。

ELPI と SMPS の測定原理は異なるが, セバシン酸ジ オクチルのエアロゾル $\left(0.92 \mathrm{~g} \mathrm{~cm}^{-3}\right)$ を用いた両装置 による個数濃度測定值はよく一致することが報告されて いる ${ }^{26)}$ 。本研究で使用した ELPI と SMPS については, 実験室内空気を用いた精度確認試験を実施し, 両者の測 定結果が一致することを確認した。密度がほほ $1 \mathrm{~g}$ $\mathrm{cm}^{-3}$ の球形粒子であれば ELPI で測定した空気動力学 径と SMPS で測定した電気移動度径はほぼ一致するた め両者の測定值は一致するが, 本研究で測定した焼却炉 排ガス中粒子は密度や形状も異なるため, 厳密には空気
動力学径と電気移動度径も異なると推定される。そこで 本研究では便宜的に両者の測定值は等しいものと仮定し た。また, 個数濃度から質量濃度への換算は, 測定され た空気動力学径より, 粒子は密度 $1 \mathrm{~g} \mathrm{~cm}^{-3}$ の球体と仮 定して行った。

\section{3 試料採取および測定}

仮設減容化施設のバグフィルタNo.1の入口側にて公 定法による試料採取と, 粒径別の粒子個数濃度を把握す るための ELPI を用いた試料採取とを並行して実施した。 試料採取位置は図 1 および図 2 に示すように, 活性炭や 消石灰の吹込位置より上流である。試料採取時における 各機器の配置を図 3 に, 採取時の焼却炉排ガス温度等の 条件を表 1 に示す。試料の採取は 2015 年 10～11 月にか けて実施した。

\subsubsection{ELPI}

ELPI の前段にはサイクロン (Cyclone S110, Dekati Ltd., 吸引流量 $10 \mathrm{~L} \mathrm{~min}^{-1}$ ) を設置し, ELPI の分級上 限である $10 \mu \mathrm{m}$ 以上の粒子を除去した後に焼却炉排ガ スをELPIへ導入した。ELPI の吸引流量はサイクロン と同様に $10 \mathrm{~L} \mathrm{~min}^{-1}$ とした。降では, サイクロンで $10 \mu \mathrm{m}$ 以上のばいじんを除いた粒子を $\mathrm{PM}_{10}$ と略記する。 また，燒却炉排ガスが凝縮することを防ぐため，サイク ロンから ELPI までの配管, ELPI のチャージャ部とイ ンパクタ部を $180{ }^{\circ} \mathrm{C}$ に加温した。バグフィルタ入口側で は焼却炉排ガス中のばいじん濃度が数 $\mathrm{g} \mathrm{m}^{-3}{ }_{\mathrm{N}}$ と高い ${ }^{27)}$ ことが想定されたことから，目詰まりおよび再飛散によ 


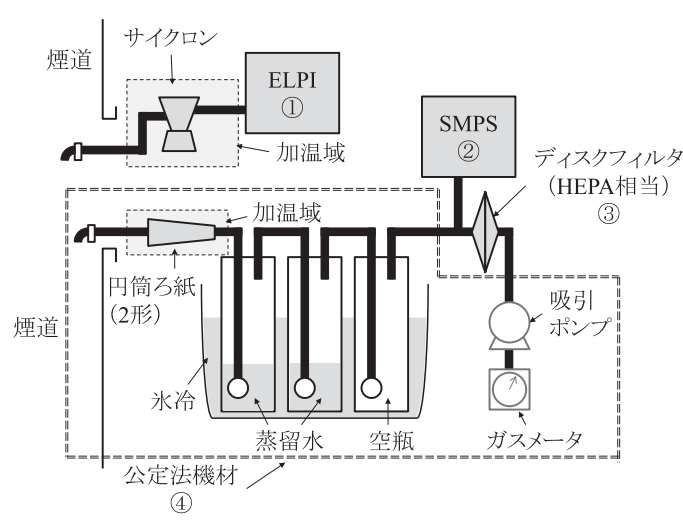

(1)：バグフィルタ入口, (2)：インピンジャ出口, (3)：ディスク フィルタ, (4)公定法機材

サイクロン：10 $\mu \mathrm{m}$ 以上の粒子の分離，吸引流量 $10 \mathrm{~L} \mathrm{~min}^{-1}$ ELPI : 粒子個数濃度測定, 吸引流量 $10 \mathrm{~L} \mathrm{~min}^{-1}$ SMPS : 粒子個数濃度測定, 吸引流量 $1 \mathrm{~L} \mathrm{~min}^{-1}$ ガスメータ: 吸引流量 $7.6 \sim 8.4 \mathrm{~L} \mathrm{~min}^{-1}$

図 3 試料採取時の機器配置

表 1 試料採取時の焼却炉排ガス条件

\begin{tabular}{lcc}
\hline & $\mathrm{A}$ 施設 & B 施設 \\
\hline 排ガス流速 $\left[\mathrm{m} \mathrm{s}^{-1}\right]$ & $8.49 \sim 8.77$ & $12.7 \sim 13.4$ \\
排ガス温度 $\left[{ }^{\circ} \mathrm{C}\right]$ & $168 \sim 175$ & $170 \sim 177$ \\
水分量 $[\%]$ & $40.9 \sim 41.5$ & $42.9 \sim 44.1$ \\
\hline
\end{tabular}

るELPIの分級性能への影響を避けるため, ELPIによ る焼却炉排ガスの採取時間を 5 分間程度とした。なお, 焼却炉排ガスを清浄空気で希釈することで採取時間を長 くできる可能性があるが, 希釈後の焼却炉排ガス粒子の 粒径分布が元の煙道内の状態から変化することが予想さ れたため, 本研究では希粕を行わなかった。以上の測定 を4回繰り返した。

\subsection{2 公定法㧍よびSMPS}

公定法による試料採取は円筒ろ紙（No. 88RH，アド バンテック東洋(秼) を用い，2 形で実施した。公定法の 試料採取系を図 3 (4) (二重点線部) に示す。公定法によ る試料採取を行う際に, 試料採取ラインのインピンジャ 出口側における粒子個数濃度を測定するために図 3 (2)に 示した位置にSMPSを設置した。インピンジャ出口よ り下流には, インピンジャ出口側にて検出される可能性 のある粒子を回収するための HEPA フィル夕相当（粒 径 $0.3 \mu \mathrm{m}$ の粒子を $99.97 \%$ 捕捉する性能）のディスク フィルタ (Pallflex 2500 QAT-UP, Pall Corp.) を設置 した（図 3 (3))。公定法による試料採取は 1 回あたり 1 時間程度行った。インピンジャ出口側に設置したSMPS による粒子個数濃度の測定も同時に行い, そのうちの 15 分間を解析対象とした。以上の測定を 4 回繰り返し た。
公定法によって採取したばいじんとドレン水，および ディスクフィルタはそれぞれゲルマニウム半導体検出器 (GC2020, ミリオンテクノロジーズキャンベラ侏) を用 いて放射性セシウム濃度を測定した。放射性セシウムの 減衰補正の基準日は試料採取日とした。

\section{4 捕集効率の評価}

公定法で用いた円筒ろ紙は $0.3 \mu \mathrm{m}$ のフタル酸ジオク チル粒子を分散させた大気を $5 \mathrm{~L} \mathrm{~min}^{-1}$ で通気させたと きの捕集効率がカタログ值で $>99.9 \%$ とされている。 一方で, ガスメー夕の吸引流量から換算した煙道内での 公定法による採取流量は，湿りガスとして 10.7〜 13.9 L $\min ^{-1}$ (公定法では $15 \mathrm{~L} \mathrm{~min}^{-1}$ 以下が目安) であり, 実 際の採取流量では円筒ろ紙がカタログ上の性能を担保で きない可能性がある。そこで, 円筒ろ紙に扔ける微小粒 子の捕集効率は, ELPI と SMPS 測定粒径範囲のうち, 両者で共通している粒径 $0.3 \mu \mathrm{m}$ 末満の粒子を評価の対 象とした。

ELPI で測定したバグフィルタ入口（図 3 (1)）の測定 結果は, 円筒ろ紙部にて捕集される粒子と同一であると 考えられることから，以下ではバグフィル夕入口（図 3 (1)）の測定結果を円筒万紙入口と表記する。円筒万紙入 口に扔ける粒子個数濃度と, 公定法のインピンジャ出口 （図 3 (2)）にてSMPS で測定した粒子個数濃度を用いて, 公定法の試料採取系における個数基準の粒子捕集効率 (以下, 粒子捕集効率) を求めた。粒子捕集効率を算出 する際には, 円筒ろ紙入口とインピンジャ出口の測定結 果を標準状態の乾きガス中の濃度に換算した。

\section{3. 結果と考察}

\section{1 焼却炉排ガス中の微小粒子の粒径分布}

バグフィルタ入口に抒ける $\mathrm{PM}_{10}$ の個数基準の粒径分 布関数（以下，粒径分布と略記）を図 4 に, 質量基準の 粒径分布を図 5 に示す。 $\mathrm{A}$ 施設より B 施設のほうが粒 子濃度は高いが, $\mathrm{PM}_{10}$ の粒径分布は両施設でほとんど 差がみられなかった。個数基準の場合, 最も出現頻度の 高い粒径, すなわちモード径は, 粒径 (ELPI で分級さ れる各粒径範囲の代表径, $\left.D_{\mathrm{p}}\right) 0.281 \mu \mathrm{m}$ であり, 単峰 型の分布を示した。モード径に抢ける個数濃度の絶対值 は $1.0 \times 10^{6}$ 個 $\mathrm{cm}^{-3}$ 程度であった。質量基準の場合は, 図 5 に示すように粒径 $0.5 \mu \mathrm{m}$ のピークのほかに個数基

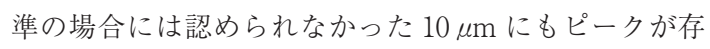
在する二峰型の分布を示した。バグフィル夕前で, 焼却 炉排ガス中のばいじんが質量基準で二峰型の分布である ことは, アンダーセン型カスケードインパクタを用いた 

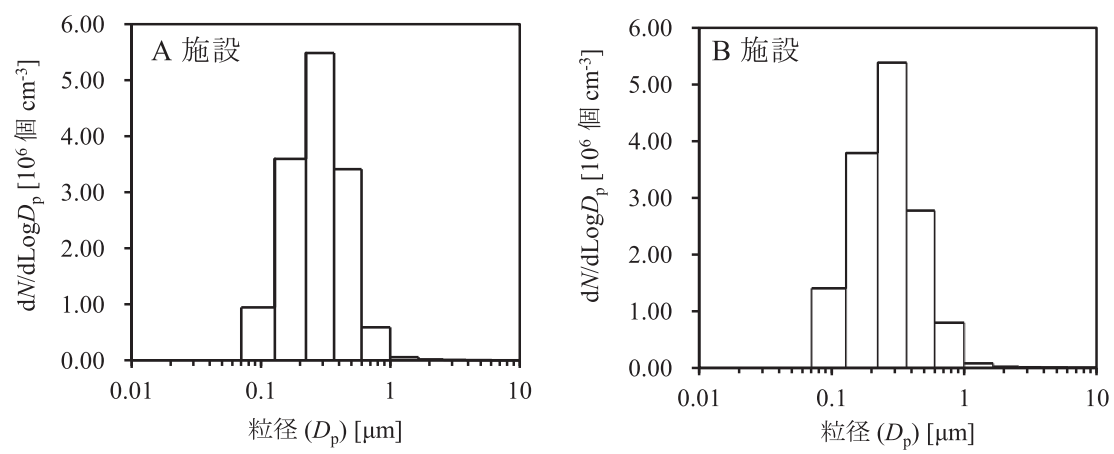

注）絴軸は実排ガス中濃度

図 4 バグフィルタ入口側の $\mathrm{PM}_{10}$ の粒径分布（個数濃度基準）
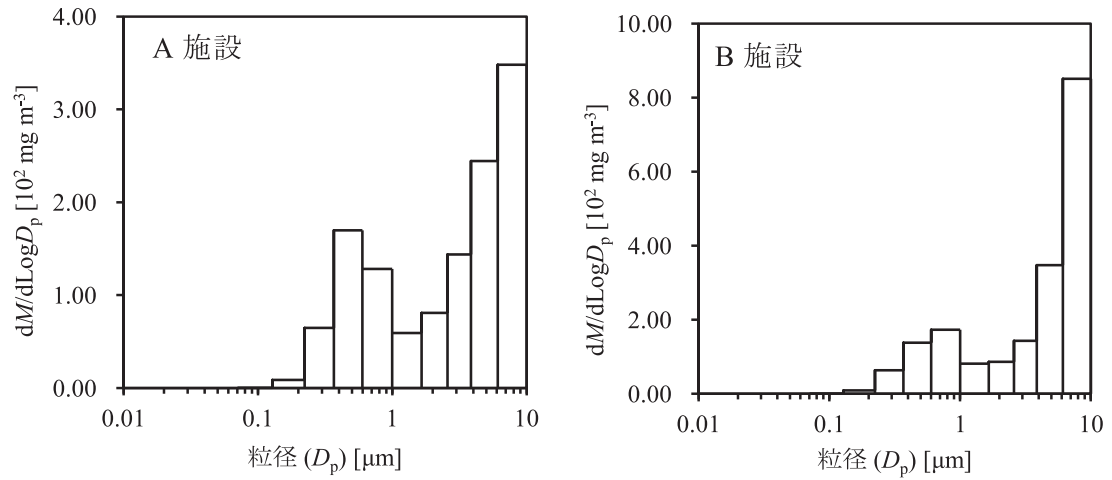

注）縦軸は実排ガス中濃度

図 5 バグフィルタ入口側の $\mathrm{PM}_{10}$ の粒径分布（質量濃度基準）

都市ごみ焼却施設に㧈ける粒径分布の測定結果 27.28$)$ と一 致している。また, 図 5 より質量基準でモード径が 10 $\mu \mathrm{m}$ 付近にみられたことは, 両施設とも煙道内では $2 \mu \mathrm{m}$ 以上の粗大粒子の占める割合が大きいことを示している。

\section{2 公定法による微小粒子の捕集効率の評価}

バグフィルタ入口側㧍よびインピンジャ出口側の粒子 個数濃度と, それらから求めた公定法の試料採取系内の 粒子捕集効率の測定結果を表 2 に, 粒径別粒子捕集効率 の測定結果を表 3 に示す。なお，表 2 抢よび表 3 は ELPI と SMPS の共通の測定粒径範囲のうち, ELPI の 代表径として 0.0910 0.281 $\mu \mathrm{m}$ （ELPI の粒径区分では Stage 5〜7）に扔ける粒子個数濃度を示している。粒径 $0.1 \mu \mathrm{m}$ 未満の粒子，すなわち ELPI の粒径区分では Stage 1 4 に相当する粒子（ $D_{\mathrm{p}}$ として $0.050 \mu \mathrm{m}$ 未満） は円筒ろ紙入口側でほとんど検出されないため, 測定誤 差が大きく厳密な評価は困難と考えられた。そこで, ELPI の粒径区分に扮ける Stage 5 以上 $\left(D_{\mathrm{p}}\right.$ として $0.0910 \mu \mathrm{m}$ 以上）の粒径で，かつ ELPI と SMPS の共通
の測定粒径範囲にて評価した。結果, 円筒ろ紙入口では $10^{6}$ 個 $\mathrm{cm}^{-3}{ }_{\mathrm{N}}$ 以上の粒子が検出された。一方, インピン ジャ出口に扔いても微小粒子が検出されたが, その粒子 個数濃度は $10^{2}$ 個 $\mathrm{cm}^{-3}{ }_{\mathrm{N}}$ 程度であった。円筒ろ紙入口 とインピンジャ出口で検出した粒子個数濃度から算出し た試料採取系内の粒子捕集効率は，両施設とも $99.99 \%$ 以上であった。同様に, 各粒径別の粒子捕集効率を算出 した結果，いずれの粒径 $\left(D_{\mathrm{p}}: 0.0910 \sim 0.281 \mu \mathrm{m}\right)$ にお いても $99.99 \%$ 程度であった。

インピンジャ出口に打いて SMPS で検出された粒子 については, インピンジャ内のドレン水由来のミストの ほか, 何らかの元素化合物の凝縮性粒子の存在が考えら れた。凝縮性粒子とは, 集じん装置の入口温度では蒸気 状であるが, 煙突出口から大気拡散する際に希釈・冷却 されて粒子化する粒子 ${ }^{29}$ である。都市ごみ焼却施設での 凝縮性粒子の測定例では, 有機炭素のほか $\mathrm{Na}, \mathrm{K}, \mathrm{Mg}$, $\mathrm{Zn}$ 等の金属成分, $\mathrm{NO}_{3}{ }^{-}, \mathrm{SO}_{4}{ }^{2-}, \mathrm{NH}_{4}{ }^{+}, \mathrm{Cl}^{-}$等のイオン成 分が検出されることが報告されている ${ }^{30,31}$ 。公定法の試 料採取系は凝縮性粒子の試料採取方法と異なるが, 排ガ 
表 2 公定法の個数基準粒子捕集効率

\begin{tabular}{|c|c|c|c|c|}
\hline & & \multicolumn{2}{|c|}{ 粒子個数濃度 [個 $\left.\mathrm{cm}^{-3} \mathrm{~N}\right]$} & \multirow{2}{*}{$\begin{array}{c}\text { 粒子捕集効率 } \\
{[\%]} \\
1-\mathrm{b} / \mathrm{a}\end{array}$} \\
\hline & & $\begin{array}{c}\text { 円筒ろ紙入口 } \\
\text { (ELPI にて測定) } \\
\mathrm{a} \\
\end{array}$ & $\begin{array}{c}\text { インピンジャ出口 } \\
\text { (SMPS にて測定) } \\
\text { b }\end{array}$ & \\
\hline \multirow{5}{*}{$\mathrm{A}$ 施設 } & RUN 1 & $3.95 \times 10^{6}$ & 59 & 99.998 \\
\hline & RUN 2 & $7.57 \times 10^{6}$ & 64 & 99.999 \\
\hline & RUN 3 & $6.50 \times 10^{6}$ & 86 & 99.999 \\
\hline & RUN 4 & $6.92 \times 10^{6}$ & 139 & 99.998 \\
\hline & 平均 $\pm \sigma$ & $(6.24 \pm 1.59) \times 10^{6}$ & $87 \pm 37$ & $99.999 \pm 0.00048$ \\
\hline \multirow{5}{*}{ B 施設 } & RUN 1 & $7.21 \times 10^{6}$ & 128 & 99.998 \\
\hline & RUN 2 & $1.04 \times 10^{7}$ & 62 & 99.999 \\
\hline & RUN 3 & $3.96 \times 10^{6}$ & 276 & 99.993 \\
\hline & RUN 4 & $8.23 \times 10^{6}$ & 73 & 99.999 \\
\hline & 平均 $\pm \sigma$ & $(7.44 \pm 2.66) \times 10^{6}$ & $135 \pm 99$ & $99.998 \pm 0.0030$ \\
\hline
\end{tabular}

注）測定粒径は $D_{\mathrm{p}}: 0.0910 \sim 0.281 \mu \mathrm{m}$

表 3 粒子個数濃度から求めた公定法の粒径別粒子捕集効率

\begin{tabular}{|c|c|c|c|c|}
\hline & \multirow[b]{2}{*}{$\begin{array}{c}\text { 粒径 }\left(D_{\mathrm{p}}\right) \\
{[\mu \mathrm{m}]}\end{array}$} & \multicolumn{2}{|c|}{ 粒子個数濃度 $\left[\right.$ 個 $\left.\mathrm{cm}^{-3} \mathrm{~N}\right]$} & \multirow{2}{*}{$\begin{array}{c}\text { 粒子捕集効率 } \\
{[\%]} \\
1-\mathrm{b} / \mathrm{a}\end{array}$} \\
\hline & & $\begin{array}{c}\text { 円筒ろ紙入口 } \\
\text { (ELPI にて測定) } \\
\text { a }\end{array}$ & $\begin{array}{c}\text { インピンジャ出口 } \\
\text { (SMPS にて測定) } \\
\text { b }\end{array}$ & \\
\hline \multirow{4}{*}{$\mathrm{A}$ 施設 } & 0.0910 & $(6.72 \pm 4.15) \times 10^{5}$ & $33 \pm 17$ & $99.995 \pm 0.0013$ \\
\hline & 0.165 & $(2.57 \pm 0.921) \times 10^{6}$ & $25 \pm 12$ & $99.999 \pm 0.00030$ \\
\hline & 0.281 & $(3.00 \pm 0.587) \times 10^{6}$ & $29 \pm 10$ & $99.999 \pm 0.00046$ \\
\hline & 全体 & $(6.24 \pm 1.59) \times 10^{6}$ & $87 \pm 37$ & $99.999 \pm 0.00048$ \\
\hline \multirow{4}{*}{ B 施設 } & 0.0910 & $(1.11 \pm 0.622) \times 10^{6}$ & $60 \pm 68$ & $99.987 \pm 0.022$ \\
\hline & 0.165 & $(3.02 \pm 1.36) \times 10^{6}$ & $49 \pm 28$ & $99.998 \pm 0.0026$ \\
\hline & 0.281 & $(3.30 \pm 1.02) \times 10^{6}$ & $26 \pm 19$ & $99.999 \pm 0.00082$ \\
\hline & 全体 & $(7.44 \pm 2.66) \times 10^{6}$ & $135 \pm 99$ & $99.998 \pm 0.0030$ \\
\hline
\end{tabular}

注）測定粒径は $D_{\mathrm{p}}: 0.0910 \sim 0.281 \mu \mathrm{m}$, 平均值士標準偏差（б）を表記

表 4 公定法の粒径別質量基準捕集効率

\begin{tabular}{|c|c|c|c|c|}
\hline & \multirow[b]{2}{*}{$\begin{array}{c}\text { 粒径 }\left(D_{\mathrm{p}}\right) \\
{[\mu \mathrm{m}]}\end{array}$} & \multicolumn{2}{|c|}{ 粒子質量濃度 $\left[\mu \mathrm{g} \mathrm{m}^{-3}{ }_{\mathrm{N}}\right]$} & \multirow{2}{*}{$\begin{array}{c}\text { 質量基準 } \\
\text { 捕集効率 }[\%] \\
1-\mathrm{b} / \mathrm{a}\end{array}$} \\
\hline & & $\begin{array}{c}\text { 円筒ろ紙入口 } \\
\text { (ELPI にて測定) } \\
\text { a }\end{array}$ & $\begin{array}{c}\text { インピンジャ出口 } \\
\text { (SMPS にて測定) } \\
\text { b }\end{array}$ & \\
\hline \multirow{4}{*}{$\mathrm{A}$ 施設 } & 0.0910 & $275 \pm 170$ & $0.0128 \pm 0.00777$ & $99.995 \pm 0.00093$ \\
\hline & 0.165 & $6,260 \pm 2,250$ & $0.0740 \pm 0.0322$ & $99.999 \pm 0.00033$ \\
\hline & 0.281 & $35,400 \pm 6,940$ & $0.339 \pm 0.115$ & $99.999 \pm 0.00048$ \\
\hline & 全体 & $42,000 \pm 8,600$ & $0.426 \pm 0.142$ & $99.999 \pm 0.00046$ \\
\hline \multirow{4}{*}{ B 施設 } & 0.0910 & $456 \pm 255$ & $0.0266 \pm 0.0304$ & $99.994 \pm 0.024$ \\
\hline & 0.165 & $7,380 \pm 3,310$ & $0.127 \pm 0.0704$ & $99.998 \pm 0.0025$ \\
\hline & 0.281 & $39,000 \pm 12,000$ & $0.286 \pm 0.218$ & $99.999 \pm 0.00078$ \\
\hline & 全体 & $46,900 \pm 14,600$ & $0.439 \pm 0.131$ & $99.999 \pm 0.00091$ \\
\hline
\end{tabular}

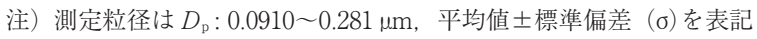

ス中に含まれる凝縮性の成分はろ紙部では蒸気状で存在 し，インピンジャ内のドレン水で液体捕集され，うち一 部は凝縮性粒子として SMPSにて検出された可能性も 考えられた。そこで, 別途, 試験実施場所にてディスク フィルタで除粒子した周辺環境大気をインピンジャに
通気（ガスメータ吸引流量 $6.2 \mathrm{~L} \mathrm{~min}^{-1}$ ) し, インピン ジャ出口に設置したSMPSにて粒子個数濃度を測定 した結果，56〜88 個 $\mathrm{cm}^{-3}{ }_{\mathrm{N}}$ の粒子 $\left(D_{\mathrm{p}}: 0.0910 \sim 0.281\right.$ $\mu \mathrm{m})$ が検出された。焼却炉排ガスを採取した場合と, 周辺環境大気をインピンジャへと吹き込んだ場合とでイ 
ンピンジャ出口から検出された微小粒子の個数濃度に大 きな差異が認められなかったことから, SMPS で検出さ れた粒子はインピンジャ内で生成したドレン水由来のミ ストに大部分が由来するものと考えられた。

粒子を密度が $1 \mathrm{~g} \mathrm{~cm}^{-3}$ の球体と仮定して算出した質 量濃度から求めた捕集効率（以下，質量基準捕集効率） を表 4 に示す。粒子個数濃度の結果と同様, いずれの粒 径においても質量基準捕集効率は $99.99 \%$ 程度であった。 円筒ろ紙のカタログ上の質量基準捕集効率は $5 \mathrm{~L} \mathrm{~min}^{-1}$ の条件で試験した結果であるが, 実際の煙道内での採取

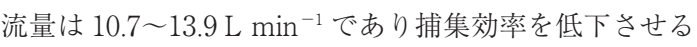
可能性がある。さらに, 今回の検証試験でインピンジャ 出口にて検出された粒子は, 焼却炉排ガス中に含まれる 微小粒子以外に, インピンジャ内のドレン水由来のミス 卜等を含む可能性があるため, インピンジャ出口の粒子 個数は試料採取系内で新たに発生した粒子が上乗せされ ていると考えられる。ゆえに，公定法の試料採取系内に おける焼却炉排ガス中に含まれる微小粒子の粒子捕集効 率を過小評価している可能性がある。それにもかかわら ず個数濃度基準・質量濃度基準ともに粒径 $0.3 \mu \mathrm{m}$ 未満 の粒子全体で $99.99 \%$ 以上の粒子捕集効率が得られたこ とは，公定法は焼却炉排ガスの試料採取条件においても 十分に微小粒子を捕集できることを示すものである。

\section{3 インピンジャ出ロから検出される粒子と公定法の 評価}

公定法によって採取したばいじん試料（円筒ろ紙部） およびドレン水の放射性セシウム濃度, インピンジャ出 口側に設置したディスクフィルタ（図 3 (3)）の放射性セ シウム濃度を測定した。結果を表 5 に示す。円筒ろ紙か らは放射性セシウムが検出され， B 施設では数百 $\mathrm{Bq}$ $\mathrm{m}^{-3}{ }_{\mathrm{N}}$ のオーダーであった。一方, ドレン水からはすべて
の試料で検出下限值未満であった。なお, 今回の調査で は試料採取時間が 1 時間と短かったため, 放射性セシウ ムの検出下限值は公定法の目標值よりやや高い值となっ ている。また, インピンジャ出口からは表 2 に示したよ うに粒子がわずかに検出された。これをディスクフィル 夕にて捕集し，放射性セシウム濃度の測定を行った結果， すべて検出下限值未満であったことから, インピンジャ 出口で検出された粒子はインピンジャ内で生成したミス トであると考えられた。小型管状炉による安定セシウム を用いた試験等による既往研究と同様に, 稼働中の仮設 減容化施設における試料採取においても, 公定法による 試料採取方法では放射性セシウムのほぼ全量がろ紙部に 捕集されることを確認した。

\section{4. まと め}

バグフィルタ入口側の燒却炉排ガス中に含まれる粒子 の粒径分布を測定した結果, 質量基準では都市ごみ焼却 施設における粒径分布 ${ }^{27,28)}$ と同様の二峰型の分布を示し た。

バグフィルタ入口側にて粒子個数濃度測定による公定 法の粒子捕集効率を評価した結果, $0.3 \mu \mathrm{m}$ 未満の微小 粒子の粒子捕集効率は $99.99 \%$ 以上であり, 焼却炉排ガ スの試料採取条件においても円筒ろ紙の性能は十分に保 持するものであった。また，公定法で採取した円筒ろ紙 等の放射性セシウム濃度を測定した結果, 既報 ${ }^{13-16)}$ と同 様にすべて円筒ろ紙から検出され，ドレン水およびイン ピンジャ出口に設置した微小粒子採取用のディスクフィ ルタからは放射性セシウムは検出されなかった。以上の ことから, JIS Z 8808 「排ガス中のダスト濃度測定方法」 に準拠する公定法は, 焼却炉排ガス中の放射性セシウム 濃度測定のための試料採取方法として適切であることが

表 5 公定法によって採取した排ガス試料の放射性セシウム濃度

\begin{tabular}{|c|c|c|c|c|c|c|c|c|c|c|c|}
\hline \multirow{3}{*}{ 施設 } & & \multirow{3}{*}{$\begin{array}{c}\text { ばいじん } \\
\text { 濃度 } \\
{\left[\mathrm{g} \mathrm{m}^{-3} \mathrm{~N}\right]}\end{array}$} & \multicolumn{9}{|c|}{ 放射性セシウム濃度 $\left[\mathrm{Bq} \mathrm{m}^{-3}{ }_{\mathrm{N}}\right]^{*}$} \\
\hline & & & \multicolumn{3}{|c|}{ 円筒万紙部 } & \multicolumn{3}{|c|}{ ドレン水 } & \multicolumn{3}{|c|}{ ディスクフィルタ } \\
\hline & & & ${ }^{134} \mathrm{Cs}$ & ${ }^{137} \mathrm{Cs}$ & 合計 & ${ }^{134} \mathrm{Cs}$ & ${ }^{137} \mathrm{Cs}$ & 合計 & ${ }^{134} \mathrm{Cs}$ & ${ }^{137} \mathrm{Cs}$ & 合計 \\
\hline \multirow{5}{*}{ A } & RUN 1 & 0.63 & 6.3 & 31.2 & 37.5 & $<2.4$ & $<2.8$ & $<5.2$ & $<1.2$ & $<0.9$ & $<2.1$ \\
\hline & RUN 2 & 0.31 & 2.4 & 13.9 & 16.3 & $<2.5$ & $<3.0$ & $<5.5$ & $<0.9$ & $<0.6$ & $<1.5$ \\
\hline & RUN 3 & 0.45 & 5.0 & 17.4 & 22.4 & $<2.4$ & $<2.4$ & $<4.8$ & $<1.1$ & $<0.8$ & $<1.9$ \\
\hline & RUN 4 & 0.19 & 3.5 & 17.2 & 20.7 & $<2.7$ & $<2.8$ & $<5.5$ & $<1.0$ & $<0.8$ & $<1.8$ \\
\hline & 平均 & 0.40 & 4.3 & 19.9 & 24.2 & $<2.5$ & $<2.8$ & $<5.3$ & $<1.1$ & $<0.8$ & $<1.8$ \\
\hline \multirow{5}{*}{ B } & RUN 1 & 0.85 & 39.3 & 163 & 202 & $<2.8$ & $<3.0$ & $<5.8$ & $<2.5$ & $<1.7$ & $<4.2$ \\
\hline & RUN 2 & 2.1 & 82.7 & 346 & 429 & $<2.8$ & $<2.1$ & $<4.9$ & $<1.1$ & $<0.9$ & $<2.0$ \\
\hline & RUN 3 & 0.47 & 101 & 451 & 552 & $<2.7$ & $<2.6$ & $<5.3$ & $<1.1$ & $<0.8$ & $<1.9$ \\
\hline & RUN 4 & 0.68 & 71.8 & 281 & 353 & $<2.4$ & $<3.0$ & $<5.4$ & $<1.0$ & $<0.8$ & $<1.8$ \\
\hline & 平均 & 1.0 & 73.7 & 310 & 384 & $<2.7$ & $<2.7$ & $<5.4$ & $<1.4$ & $<1.0$ & $<2.5$ \\
\hline
\end{tabular}

* : <は検出下限值未満を表す 
検証された。

\section{[謝辞]}

本研究の取りまとめにあたっては, 環境省福島地 方環境事務所のご協力を得ました。ここに記して謝 意を表します。

\section{参考文献}

1）環境省：放射性物質污染廃棄物処理情報サイト, http : //shiteihaiki.env.go.jp/

(閲覽日 2017 年 9 月 19 日)

2 ) 環境省：廃棄物関係ガイドライン 第 5 部 放射能濃 度等測定方法ガイドライン 平成 25 年 3 月第 2 版 (2013)

3) JIS Z 8808: 2013. 排ガス中のダスト濃度測定方法

4 ) 環境省：第九回災害廃棄物安全評価検討会 資料 5 (2011)

http : //www.env.go.jp/jishin/attach/haikihyouka_ken tokai/09-mat_2.pdf（閲覧日 2017 年 9 月 19 日）

5 ) 山本貴士, 田野崎隆雄, 竹内幸生, 鈴木 剛, 滝上英孝, 大迫政浩, 酒井伸一：焼却排ガス中の放射性セシウム 測定における試料採取方法の検討, 第 1 回環境放射能 除染研究発表会要旨集, p.71（2012）

6 ) 環境省 : 第十三回災害廃棄物安全評価検討会 資料 4 (2012)

http : //www.env.go.jp/jishin/attach/haikihyouka_ken tokai/13-mat_4.pdf（閲覽日 2017 年 9 月 19 日）

7 ）環境省：第二回放射性物質污染廃棄物に関する安全対 策検討会 資料6 (2015)

https : //www.env.go.jp/jishin/rmp/conf/waste_safety 02/mat06.pdf（閲覽日 2017 年 9 月 19 日）

8 ）滝上英孝, 山本貴士, 竹内幸生, 田野崎隆雄, 鈴木 剛, 森口祐一, 大迫政浩: 廃棄物焼却排ガスの長時間採 取・測定方法に関する検討と適用, 第 2 回環境放射能 除染学会研究発表会講演要旨集, p. 89 (2013)

9) 原子力委員会: 発電用軽水型原子炉施設における放出 放射性物質の測定に関する指針 昭和 53 年 9 月 29 日 (1978)（平成元年 3 月 27 日一部改訂; 原子力安全委員 会） (1989)

10） JIS Z 4601 : 2009. 放射性ダストサンプラ

11) ISO $2889: 2010$. Sampling airborne radioactive materials from the stacks and ducts of nuclear facilities

12）高岡昌輝：廃棄物焼却施設における排ガス中放射性物 質の測定, 廃棄物資源循環学会誌, 第 24 巻, 第 4 号, pp. 258-266 (2013)

13）大阪市：放射性物質の測定方法に関する確認について, 大阪市報道発表資料（平成 24 年 10 月 11 日）（2012） http : //www.city.osaka.lg.jp/kankyo/cmsfiles/contents/ 0000388/388404/121011experiment.pdf (閲覽日 2017 年 9 月 19 日)

14）籠谷純一, 渡辺信久 : $\mathrm{CsCl}, \mathrm{KCl}$ および $\mathrm{NaCl}$ の加熱時 の揮発と捕集, 第 22 回環境化学討論会講演要旨集, pp. 442-443(2013)

15）籠谷純一, 渡辺信久：揮発した $\mathrm{NaCl}, \mathrm{KCl}$ および $\mathrm{CsCl}$ の円筒ろ紙による捕集とその破過, 第 24 回廃棄物資源 循環学会研究発表会講演論文集, pp. 473-474（2013）

16）渡辺信久, 梅崎大睦, 高橋 悠: 気相中 $\mathrm{NaCl}, \mathrm{KCl}, \mathrm{RbCl}$ および $\mathrm{CsCl}$ のろ過集じんによる捕集効率を調べる実 験, 第 26 回環境化学討論会 3D-03（2017）

17）山本貴士, 竹内幸生, 鈴木 剛, 大迫政浩 : 焼却排ガス 中セシウムの採取方法の検討, 第 27 回廃棄物資源循環 学会研究発表会講演集, pp. 497-498（2016）

18）倉持秀敏, 由井和子, 大迫政浩：焼却過程の放射性七 シウムの挙動を再現するための平衡計算の改良と評価, 第 2 回環境放射能除染学会講演要旨集, p. 64 (2013)

19）倉持秀敏, 大迫政浩, 酒井伸一：塩化七シウムの蒸気 圧測定, 第 22 回環境化学討論会, pp. 228-229 (2013)

20) K. Shiota, M. Takaoka, T. Fujimori, K. Oshita and Y. Terada: Cesium Speciation in Dust from Municipal Solid Waste and Sewage Sludge Incineration by Synchrotron Radiation Micro-X-ray Analysis, Analytical Chemistry, Vol. 81, pp. 11249-11254 (2015)

21）山本貴士, 滝上英孝, 田野崎隆雄, 竹内幸生, 鈴木 剛, 大迫政浩, 貴田晶子, 酒井伸一: 焼却プロセスにおけ る放射性セシウムの挙動について, 第 23 回廃棄物資源 循環学会研究発表会講演集, pp. 167-168（2012）

22) M. E. Kitto : Radioactivity in Size-separated Municipal Incinerator Ashes, Health Physics, Vol.62, No.6, pp. 529-536 (1992)

23）環境省：第三回災害廃棄物安全評価検討会 資料 6-3 (2011)

http : //www.env.go.jp/jishin/attach/haikihyouka_ken tokai/03-mat_5.pdf（閲覧日 2017 年 9 月 19 日）

24）JIS B 9908: 2011. 換気用エアフィルタユニット・換気 用電気集じん器の性能試験方法

25）村島淑子：気中粒子の個数基準粒径分布測定と標準に 関する調查研究, 産総研計量標準報告, 第 9 巻, 第 3 号, pp. 381-397 (2016)

26) M. Marjamäki, J. Keskinen, D.-R. Chen and D. Y. H. Pui : Performance Evaluation of the Electrical Low-pressure Impactor (ELPI), Journal of Aerosol Science, Vol. 31, No. 2, pp. 249-261 (2000)

27）塩田憲司, 今井玄哉, 高岡昌輝, 木本 成, 松井康人, 大下和徹, 水野忠雄, 森澤眞輔 : 都市ごみ焼却施設か ら排出される微小粒子へのダイオキシン類除去対策強 化による効果, 大気環境学会誌, 第 46 卷, 第 4 号, pp. 224-232 (2011)

28）米田 稔: 焼却 - 溶融処理を用いた放射能污染土䁃 - 廃 棄物の放射能分離・減容·固定化技術の確立, 平成 25 年度環境研究総合推進費補助金研究事業総合研究報告 書（3K 122106）(2014）

29）神谷秀博, 並木則和, 塚田まゆみ, Wuled Lenggoro, 和田匡司, 野田直希, 牧野尚夫, 峰島知芳, W. W. Szymanski：固定発生源におけるエアロゾルの生成と 排出挙動, エアロゾル研究, 第 29 巻, 第 $\mathrm{S} 1$ 号, pp. s27s37 (2014) 
30）小暮信之, 田森行男, 石岡 修, 井上俊明, 谷本高敏 : 凝縮性ダストを含む排ガス中の粒子濃度測定方法の調 查研究, 大気環境学会誌, 第 32 巻, 第 2 号, pp. 162173 (1997)

31) G. C. England, J. G. Watson, J. C. Chow, B. Zielinska,
M.-C. O. Chang, K. R. Loos and G. M. Hidy: Dilutionbased Emissions Sampling from Stationary Sources: Part 2-Gas-fired Combustors Compared with Other Fuel-fired Systems, Journal of the Air \& Waste Management Association, Vol. 57, No. 1, pp. 79-93 (2007)

\title{
Evaluation of Method for Radioactive Cesium in Flue Gas by Measurement of Particle Number Concentrations
}

\author{
Shota Ino*, Katsuyuki Takahashi*, Takashi Shoji**, Yuji Kashima*, Yosuke Koyama*** \\ Takashi Yamamoto**** and Masahiro Osako**** \\ * East Branch Office, Japan Environmental Sanitation Center \\ ** Head Office, Japan Environmental Sanitation Center \\ *** Center for Health and Environmental Risk Research, \\ National Institute for Environmental Studies \\ **** Center for Material Cycles and Waste Management Research, \\ National Institute for Environmental Studies \\ ${ }^{\dagger}$ Correspondence should be addressed to Katsuyuki Takahashi: \\ East Bramch Office, Japan Environmental Sanitation Center \\ (10-6 Yotsuyakami-cho, Kawasaki-ku, Kawasaki, Kanagawa 210-0828 Japan)
}

\begin{abstract}
Radioactive cesium concentrations in flue gas are measured using the official analytical method stipulated by the Ministry of the Environment. Using this method, radioactive cesium is analyzed for dust collected by filters and fluids collected in impingers. Although filters are known to collect sufficient radioactive cesium in flue gas, no detailed data are available for their ability to collect ultrafine particulate matter. Therefore, this study was conducted to evaluate the official analytical method by measuring the number concentration of particles in the actual incinerator flue gas. Results demonstrate that the number concentration of ultrafine particles (particles with $<0.3 \mu \mathrm{m}$ diameter) at the bag filter inlet is $10^{6} \mathrm{~cm}^{-3} \mathrm{~N}$, although it is $10^{2}$ $\mathrm{cm}^{-3} \mathrm{~N}$ at the outlet of the impinger. This finding demonstrates that approximately $99.99 \%$ of the ultrafine particles can be captured using the official analytical method. Furthermore, when the radioactive cesium in the collected particles at the outlet of the impinger was analyzed, its concentration was found to be below the limits of detection. This finding confirms that the official analytical method is appropriate for taking samples of radioactive cesium in flue gas.
\end{abstract}

Keywords : flue gas, radioactive cesium, ultrafine particle, electrical low pressure impactor (ELPI), scanning mobility particle sizer (SMPS) 